\title{
ANALISIS BERBAGAI STRATEGI DAN MODEL PEMBELAJARAN YANG DAPAT MEMBERDAYAKAN KEMAMPUAN METAKOGNITIF PADA PEMBELAJARAN BIOLOGI
}

\author{
E.Erlin ${ }^{1,2}$, A.Rahmat ${ }^{1}$, and S Redjeki ${ }^{1}$, W.Purwianingsih' \\ 1 Universitas Pendidikan Indonesia, Jl. Dr. Setiabudi No. 229, Bandung 40154, Indonesia \\ 2 Universitas Galuh, JI RE Martadinata no.150 Ciamis. \\ erlineuis@yahoo.com
}

\begin{abstract}
At this time one of the problems found in the field of education is student learning outcomes are still low. The hope of students to have higher order thinking skills has not been realized. One of the causing factors this problem is not having the ability to make the right self regulation in learning. This is certainly related to the students' metacognitive abilities. , namely the self regulation component in metacognitive which includes aspects of planning before learning, monitoring during learning, and evaluating after learning in each learning activity. This study aims to provide an overview of the results of research on various strategies or learning models that can empower metacognitive abilities in the field of science. The method used is the analysis of national and international journals about metacognitive learning. Based on the results of the study, it shows that several types of strategies and learning models can empower metacognitive abilities, only some of these journals do not provide specific explanations about aspects as instructions that train students to have metacognitive abilities. The contribution of this study, among others, is that educators are expected to be more effective in developing studies related to metacognitive learning, as an effort to improve metacognitive abilities that lead to student learning success.
\end{abstract}

Keywords: Metacognitive, learning model, learning strategy

\begin{abstract}
ABSTRAK
Pada saat ini salah satu permasalahan yang ditemukan dalam dunia pendidikan adalah hasil belajar siswa yang masih rendah. Harapan para siswa untuk memiliki kemampuan berpikir tingkat tinggi masih belum terealisasi.Salah satu faktor penyebab masalah ini adalah tidak memiliki kemampuan untuk membuat pengaturan yang tepat dalam belajar. Hal ini tentu terkait dengan kemampuan metakognitif yang dimiliki siswa tersebut. , yaitu komponen pengaturan (regulation ) dalam metakognitif yang meliputi aspek perencanaan sebelum belajar (planning), pemantauan selama belajar (monitoring), dan melakukan evaluasi setelah belajar (evaluating) dalam setiap kegiatan belajar. Kajian ini bertujuan memberikan gambaran dari hasil-hasil penelitian tentang berbagai strategi atau model pembelajaran yang dapat memberdayakan kemampuan metakognitif pada bidang sains. Metode yang dilakukan yaitu analisis jurnal-jurnal Nasional dan Internasional tentang pembelajaran metakognitif. Berdasarkan hasil kajian menunjukkan bahwa beberapa jenis strategi dan model pembelajaran dapat memberdayakan kemampuan metakognitif, hanya pada beberapa jurnal tersebut tidak memberikan penjelasan yang spesifik tentang aspek-aspek sebagai instruksi yang melatih siswa untuk memiliki kemampuan metakognitif. Kontribusi kajian ini antara lain bagi para pendidik diharapkan lebih efektif dalam mengembangkan penelitian-penelitian yang terkait pembelajaran metakognitif , sebagai upaya untuk meningkatkan kemampuan metakognitif yang mengarah pada keberhasilan belajar siswa.
\end{abstract}

Kata Kunci : Metakognitif, model pembelajaran, strategi pembelajaran

Cara sitasi: Erlin, E., Rahmat, A., Redjeki, S. \& Purwianingsih, W. (2021). Analisis Berbagai Strategi dan Model Pembelajaran yang Dapat Memberdayakan Kemampuan Metakognitif pada Pembelajaran Biologi. Bioed: Jurnal Pendidikan Biologi, 9 (2), 30-40. 


\section{PENDAHULUAN}

Pada abad 21 ini salah satu yang menjadi fokus pembicaraan adalah berbagai keterampilan yang harus dimilki seseorang untuk mencapai kesuksesan hidup, sehingga diharapkan pendidikan dapat mempersiapkan siswa untuk menguasai berbagai keterampilan tersebut agar menjadi pribadi yang sukses dalam hidup. Keterampilan-keterampilan penting di abad ke-21 masih relevan dengan empat pilar kehidupan yang mencakup learning to know, learning to do, learning to be dan learning to live together. Empat prinsip tersebut masing-masing mengandung keterampilan khusus yang perlu diberdayakan dalam kegiatan belajar, seperti keterampilan berpikir kritis, pemecahan masalah, metakognisi, keterampilan berkomunikasi, berkolaborasi, inovasi dan kreasi, literasi informasi, dan berbagai keterampilan lainnya. Salah satu cara untuk mencapai keterampilan abad ke-21 tersebut dilakukan dengan memperbarui kualitas pembelajaran.

Mahasiswa masih kurang mampu dalam merancang suatu proses penemuan sendiri. Keadaan ini tentu sangat dipengaruhi oleh kemampuan berpikirnya, baik itu berpikir kritis, logis ,kreatif atau memecahkan masalah. Mahasiswa kurang mampu menggunakan strategi belajar yang sesuai, belajar hanya secara hapalan. Kelemahan -kelemahan ini terjadi, salah satu faktor penyebabnya antara lain kurangnya kemampuan metakognitif. Kurangnya kemampuan metakognitif mengakibatkan siswa menjadi kurang dapat menggunakan strategi belajar yang sesuai sehingga belajar hanya secara hafalan dan merasa bosan. Kemampuan metakognitif yaitu kesadaran tentang kognitif diri sendiri, bagaimana kognitif bekerja, serta bagaimana mengaturnya. Siswa mengetahui kemampuan dan modalitas belajar yang dimiliki dan mengetahui strategi belajar terbaik untuk belajar efektif. Pembentukan kemampuan metakognitif ini akan melahirkan proses-proses kognitif yang diperlukan untuk memecahkan masalah dalam kehidupan sehari-hari. Kurangnya kemampuan metakognitif juga berdampak pada pemikiran siswa yang kurang sistematis atau kurang runtut.

Assessment and Teaching of 21st Century Skills (ATC21S) mengkategorikan keterampilan abad ke-21 menjadi 4 kategori, yaitu way of thinking, way of working, tools for working dan skills for living in the world (Griffin, McGaw \& Care, 2012). Way of thinking mencakup creativity and inovation, problem solving, decisien making, critical thinking, learning to learn dan metacognition. Berdasarkan pernyataan tersebut, kemampuan metakognitif salah satu yang menjadi sasaran untuk dikembangkan. Alasan mengapa kemampuan metakognitif ini perlu dikembangkan, karena kemampuan metakognitif menjadi penunjang terbentuknya proses-proses kognitif. Perkembangan kognitif dianggap sebagai penentu kecerdasan intelektual. Terdapat hubungan tinggi antara metacognitive self regulation dengan berpikir kritis. Metacognitive self regulation memberikan kontribusi yang tinggi terhadap kemampuan berpikir kritis ( Gurcay D, Ozturk H,2018 ). Kemampuan kognitif terus berkembang seiring dengan proses pendidikan serta dipengaruhi juga oleh faktor perkembangan fisik terutama otak secara biologis. Perkembangan selanjutnya berkaitan dengan kognitif adalah bagaimana mengelola atau mengatur kemampuan kognitif tersebut dalam merespon situasi atau permasalahan. Tentunya, aspek-aspek kognitif tidak dapat berjalan sendiri secara terpisah tetapi perlu dikendalikan atau diatur, sehingga jika seseorang akan menggunakan kemampuan kognitifnya maka perlu kemampuan untuk menentukan dan pengatur aktivitas kognitif apa yang akan digunakan. Oleh karena itu, sesorang harus memiliki kesadaran tentang kemampuan berpikirnya sendiri serta mampu untuk mengaturnya. Para ahli mengatakan kemampuan ini disebut dengan metakognitif. Hasil belajar kognitif tentunya akan lebih bermakna jika tidak mudah segera hilang dari ingatan. Dalam hal ini, retensi memegang peranan yang penting.Pencapaian hasil belajar kognitif dan retensi ini erat kaitannya dengan kemandirian siswa dalam belajar. Kemandirian siswa tersebut berkaitan dengan keterampilan metakognitif siswa. Keterampilan metakognitif dapat membantu mengembangkan kemampuan berpikir siswa yang selanjutnya juga berpengaruh terhadap hasil belajar siswa.

Artikel ini akan mendeskripsikan gambaran metakognitif yang meliputi pengetahuan metakognitif, peranan metakognitif dalam pembelajaran,beberapa strategi dan model pembelajaran yang dapat memberdayakan kemampuan metakognitif khususnya pada bidang sains. 


\section{METODE}

Kajian artikel ini menggunakan metode studi literature yaitu review dari hasil penelitian yang relevan dengan kajian metakognitif dari jurnal-jurnal dan dari beberapa sumber buku teks .Analisis terhadap beberapa jurnal nasional dan internasional dilakukan untuk mengkaji informasiinformasi tentang berbagai strategi atau cara dan model-model pembelajaran yang dapat memberdayakan kemampuan metakognitif.

\section{HASIL ANALISIS DAN PEMBAHASAN}

\section{A. Pengertian Metakognitif}

Istilah metakognisi hampir sering dikaitkan dengan Yohanes Flavell. Tokoh metakognisi ini menyatakan bahwa metakognisi biasanya didefinisikan sebagai pengetahuan dan kognisi tentang objek-objek kognitif, yaitu tentang segala sesuatu yang berhubungan dengan kognitif. Menurutnya, konsep metakognisi dapat diperluas mencakup sesuatu yang bersifat psikologis, seperti jika seseorang memiliki pengetahuan atau kognisi tentang emosi, motif diri sendiri, atau orang lain. Segala bentuk aktivitas pantau-diri (self-monitoring) dapat dianggap sebagai bentuk metakognisi (Flavell, 1979). Metakognitif merupakan kata sifat dari metakognisi, metakognisi merupakan kata serapan dari "metacognition" dengan prefik "meta" dan "kognisi. Meta dalam bahasa Yunani berarti "setelah" atau "di atas" dan "kognisi" berarti apa yang diketahui atau dipikirkan seseorang (Diela, 2014). Istilah metakognisi pertama kali diperkenalkan Flavell pada tahun 1979. Metakognisi secara sederhana sering digambarkan sebagai berpikir tentang berpikir. Kenyataannya gambaran tersebut tidak sesederhana seperti itu, karena terdapat beberapa perbedaan istilah atau konsep metakognisi yang sering ditemukan dalam literature dengan label dan definisi atau batasan yang berbedabeda seperti metamemori, metacomprehension (Matlin, 2003, dalam Haryani, 2011) , self-regulation, executive control (Livingston, 1997). Flavel mendefinisikan metakognisi sebagai pengetahuan tentang kognisi dan pengontrolan kognisi. Menurutnya segala bentuk aktivitas pantau-diri (selfmonitoring), pengaturan-diri (self-regulation) dan efikasi-diri (self-eficacy) dapat dianggap sebagai bentuk metakognisi. Metakognisi menggambarkan suatu proses berpikir yang lebih tinggi, sesuatu yang bersifat reflektif dan terus bergerak melampaui tingkatan berpikir normal dalam merefleksikan berpikir itu sendiri (Larkin,2010 dalam Murtadho, 2013). Metakognisi mencakup pemahaman dan keyakinan pembelajar mengenai proses kognitifnya sendiri dan bahan pelajaran yang akan dipelajari, serta usaha-usaha sadarnya untuk terlibat dalam proses berperilaku dan berpikir yang akan meningkatkan proses belajar dan memorinya (Ormrod, 2009). Berpikir dihasilkan dari metakognisi yang dimiliki setiap manusia. Secara ringkas dapat dinyatakan bahwa metakognisi adalah kesadaran (awarenes) seseorang tentang proses pemantauan (monitoring) serta menjaga dan mengendalikan (regulating dan controling) pikiran dan tindakannya sendiri. Dengan demikian, metakognisi amat diperlukan dalam kegiatan berpikir siswa. Melalui metakognisi, pikiran dapat dijaga, direncanakan, dikendalikan dan dikontrol (John H.Flavel dan Patricia H.Miller,1993 dalam Murtadho, 2013).

Metakognisi merujuk pada berpikir tingkat tinggi yang melibatkan kontrol aktif dalam proses kognitif belajar. Kegiatan seperti perencanaan bagaimana pendekatan tugas belajar yang diberikan, pemantauan pemahaman, dan mengevaluasi kemajuan penyelesaian tugas adalah metakognitif alami. Metakognisi adalah kemampuan berpikir di mana yang menjadi objek berpikirnya adalah proses berpikir yang terjadi pada diri sendiri. Dalam konteks pembelajaran, siswa mengetahui bagaimana untuk belajar, mengetahui kemampuan dan modalitas belajar yang dimiliki, dan mengetahui strategi belajar terbaik untuk belajar efektif. Metakognisi sebagai suatu bentuk kemampuan untuk melihat pada diri sendiri sehingga apa yang dia lakukan dapat terkontrol secara optimal. Para peserta didik dengan pengetahuan metakognisinya sadar akan kelebihan dan keterbatasannya dalam belajar. Artinya saat siswa mengetahui kesalahannya, mereka sadar untuk mengakui bahwa mereka salah, dan berusaha 
untuk memperbaikinya (Sastrawati, 2011). Menurut Anderson (2010), pengetahuan metakognitif adalah pengetahuan tentang kognisi secara umum dan kesadaran akan, serta pengetahuan tentang, kognisi diri sendiri. Beragam teori memberi nama akan hal ini dengan sebutan pengetahuan metakognitif, kesadaran metakognitif, kesadaran diri, swarefleksi, dan swaregulasi.

Menurut Marzano (2008) metakognitf yaitu suatu sistem yang berperan untuk monitoring, evaluating dan regulating yang berfungsi untuk semua jenis proses berpikir.Sistem metakognitif ini memiliki fungis : 1)specipying goals, 2)process 3)monitoring clarity 4).monitoring accuracy .Menurut Ormrod, 2009 sebagai contoh, metakognisi meliputi hal-hal berikut ini : 1). Merefleksikan hakikat umum berpikir, belajar dan pengetahuan. 2) Mengetahui batasanbatasan pembelajaran (learning) dan kapabilitas memori. 3). Mengetahui tugas-tugas belajar apa saja yang dapat dipenuhi secara realistis dalam suatu periode tertentu. 4). Merencanakan pendekatan yang masuk akal terhadap tugas belajar. 5). Mengetahui dan mengaplikasikan strategi-strategi yang efektif untuk belajar dan mengingat materi baru. 6). Memonitor pengetahuan dan pemahaman seseorang, misalnya mengenali ketika seseorang sudah atau belum mempelajari sesuatu dengan sukses. Sedangkan menurut Lee dan Fensham, (1996 dalam Simamora ,2014) yang menyatakan kemampuan metakognisi melibatkan proses merancang, mengawal dan memantau proses pelaksanaan serta menilai setiap tindakan yang diambil mempunyai peranan yang amat penting dalam proses pembelajaran.

Metakognisi merupakan suatu proses membangkitkan minat sebab seseorang menggunakan proses kognitif untuk merenungkan proses kognitif mereka sendiri. Metakognisi sangat penting karena pengetahuan tentang proses kognitif dapat menuntun siswa didalam menyusun dan memilih strategi untuk memperbaiki kinerja positif. Dengan demikian metakognisi berhubungan dengan pengetahuan seseorang tentang proses kognitif mereka sendiri dan kemampuan menggunakan proses tersebut. Siswa perlu menyadari akan kelebihan dan kekurangan dari kemampuan kognitifnya dan berupaya menggorganisasikannya untuk diterapkan secara tepat dalam penyelesaian tugas atau masalah (Kuntjojo, 2009 dalam Sastrawati, 2011).

Pengetahuan metakognitif yang dikemukakan oleh pakar di atas sangat beragam, namun pada hakekatnya pengetahuan metakognitif menekankan kepada kesadaran seseorang mengenai proses atau cara berpikir atas pengetahuan dirinya sendiri dengan mengolah informasi dan mengatur strategi berpikirnya. Pengetahuan metakognitif berperan penting dalam mengatur kognitif seseorang sehingga dapat menunjang keberhasilan dalam pembelajaran. Pengetahuan tentang kognisi merupakan kesadaran seseorang terhadap pengetahuannya, kecenderungan belajar, gaya, kekuatan, kelemahan, factor-faktor yang akan berdampak pada kinerjanya, pengetahuan strategi, dan pengetahuan tentang kapan dan bagaimana menggunakan strategi (Magno, 2010: Lai, 2011). Pengontrolan kognisi merupakan aspek control dari belajar. Pengetahuan tentang kognisi diuraikan menjadi pengetahuan deklaratif, pengetahuan procedural, dan pengetahuan kondisional. Sedangkan pengontrolan kognisi meliputi perencanaan, strategi pengaturan informasi, pemantauan komprehensi, strategi memperbaiki kesalahan (debugging strategies), dan evaluasi. Senada dengan pendapat Flavel ( 1979 ) pengetahuan metakognitif dibagi ke dalam tiga kategori yaitu pengetahuan deklaratif (declarative knowledge), pengetahuan prosedural (procedural knowledge), dan pengetahuan kondisional (conditional knowledge).

Selain itu menurut OLRC News, 2004; Schraw \& Moshman, 1995 dalam Sastrawati, 2011 menyatakan bahwa komponen metakognisi, yaitu pengetahuan tentang kognisi (knowledge about cognition) dan regulasi kognisi (regulation of cognition). Pengetahuan tentang kognisi terdiri dari pengetahuan deklaratif (declarative knowledge), pengetahuan prosedural (procedural knowledge) dan pengetahuan kondisional (conditional knowledge). Sedangkan regulasi tentang kognisi (regulation about cognition) terdiri dari: a) Perencanaan (planning), b) 
Strategi mengelola informasi (information management strategies), c) Pemantauan terhadap pemahaman (comprehension monitoring), d) Strategi Perbaikan (debugging strategies), dan e) Evaluasi (evaluation).

\section{b. Peranan Metakognitif Dalam Pembelajaran}

\section{1). Keberhasilan Belajar}

Metakognitif pada dasarnya adalah kemampuan belajar bagaimana seharusnya belajar dilakukan yang didalamnya dipertimbangkan dan dilakukan aktivitas-aktivitas sebagai berikut (Taccasu Project, 2008) : Mengembangkan suatu rencana kegiatan belajar Mengidentifikasi kelebihan dan kekurangannya berkenaan dengan kegiatan belajar.Menyusun suatu program belajar untuk konsep, keterampilan, dan ide-ide yang baru.Mengidentifkasi dan menggunakan pengalamannya sehari-hari sebagai sumber belajar.Memanfaatkan teknologi modern sebagai sumber belajar.Memimpin dan berperan serta dalam diskusi dan pemecahan masalah kelompok.Belajar dari dan mengambil manfaat pengalaman orang-orang tertentu yang telah berhasil dalam bidang tertentu. Memahami faktor-faktor pendukung keberhasilan belajarnya. Berdasarkan apa yang dipaparkan ini, dapat dinyatakan bahwa keberhasilan seseorang dalam belajar dipengaruhi oleh kemampuan metakognisinya. Jika setiap kegiatan belajar dilakukan dengan mengacu pada indikator dari learning how to learn maka hasil optimal akan mudah dicapai.

\section{2). Pengembangan Metakognitif dalam Pembelajaran}

Mengingat pentingnya peranan metakognisi dalam keberhasilan belajar, maka upaya untuk meningkatkan hasil belajar peserta didik dapat dilakukan dengan meningkatkan metakognisi mereka. Mengembangkan metakognisi pembelajar berarti membangun fondasi untuk belajar secara aktif. Guru sebagai sebagai perancang kegiatan belajar dan pembelajaran, mempunyai tanggung jawab dan banyak kesempatan untuk mengembangkan metakognisi pembelajar. Strategi yang dapat dilakukan guru atau dosen dalam mengembangkan metakognisi peserta didik melalalui kegiatan belajar dan pembelajaran adalah sebagai berikut (Taccasu Project, 2008) :

Membantu peserta didik dalam mengembangkan strategi belajar mengajar, dengan cara:Mendorong pembelajar untuk memonitor proses belajar dan berpikirnya. Membimbing pembelajar dalam mengembangkan strategi-strategi belajar yang efektif. Meminta pembelajar untuk membuat prediksi tentang informasi yang akan muncul atau disajikan berikutnya berdasarkan apa yang mereka telah baca atau pelejari. Membimbing pembelajar untuk mengembangkan kebiasaan bertanya. Menunjukkan kepada pembelajar bagaimana teknik mentransfer pengetahuan, sikap-sikap, nilai-nilai, keterampilan-keterampilan dari suatu situasi ke situasi yang lain.

Membimbing pembelajar dalam mengembangkan kebiasaan peserta didik yang baik melalui: Pengembangan kebiasaan mengelola diri sendiri dapat dilakukan dengan : mengidentifikasi gaya belajar yang paling cocok untuk diri sendiri (visual, auditif, kinestetik, deduktif, atau induktif); memonitor dan meningkatkan kemampuan belajar (membaca, menulis, mendengarkan, mengelola waktu, dan memecahkan masalah); memanfaatkan lingkungan belajar secara variatif (di kelas dengan ceramah, diskusi, penugasa, praktik di laboratorium, belajar kelompok, dst).

Pengembangan kebiasaan mengelola diri sendiri dapat dilakukan dengan : mengidentifikasi gaya belajar yang paling cocok untuk diri sendiri (visual, auditif, kinestetik, deduktif, atau induktif); memonitor dan meningkatkan kemampuan belajar (membaca, menulis, mendengarkan, mengelola waktu, dan memecahkan masalah); memanfaatkan lingkungan belajar secara variatif (di kelas dengan ceramah, diskusi, penugasa, praktik di laboratorium, belajar kelompok, dst). 
Mengembangkan kebiasaan untuk berpikir positif. Kebiasaan berpikir positif dikembangkan dengan : meningkatkan rasa percaya diri (self-confidence) dan rasa harga diri (self-esteem) dan mengidentifikasi tujuan belajar dan menikmati aktivitas belajar.

Mengembangkan kebiasaan untuk berpikir secara hirarkhis. Kebiasaan untuk berpikir secara hirarkhis dikembangkan dengan : membuat keputusan dan memecahkan masalah dan memadukan dan menciptakan hubungan-hubungan konsep-konsep yang baru.

Mengembangkan kebiasaan untuk bertanya .Kebiasaan bertanya dikembangkan dengan : mengidentifikasi ide-ide atau konsep-konsep utama dan bukti-bukti pendukung; membangkitkan minat dan motivasi; dan memusatkan perhatian dan daya ingat, Pengembangan metakognisi pembelajar dapat pula dilakukan dengan aktivitas-aktivitas yang sederhana kemudian menuju ke yang lebih rumit.

3. Beberapa Strategi atau Model Pembelajaran yang dapat Memberdayakan Kemampuan Metakognitif pada Bidang Sains

Beberapa hasil penelitian tentang model dan strategi pembelajaran yang mengkaji metakognitif dalam bidang Sains antara lain : Pada penerapan jurnal belajar, terjadi peningkatan keterampilan metakognitif dari $73 \%$ menjadi $82 \%$ yaitu sebesar $9 \%$. Hasil tersebut menunjukkan bahwa penerapan jurnal belajar yang dilakukan setiap kali pertemuan, pada akhir pertemuan memberikan kontribusi pada peningkatan keterampilan metakognitif mahasiswa. Pernyataan tersebut ditegaskan oleh hasil penelitian yang pernah dilakukan oleh Septiyana, dkk. (2013) dalam Setiawan (2015) bahwa strategi berpikir metakognitif berkorelasi positif dengan jurnal belajar $(93,8 \%$ dan sig < 0,05). Hasil penelitian serupa juga disampaikan oleh Sabilu (2008) dan Setyanto (2011) yang mengungkapkan bahwa jurnal belajar mampu meningkatkan keterampilan metakognitif siswa. Hal ini dapat terjadi karena menulis jurnal belajar merupakan salah satu media untuk refleksi. Refleksi sendiri dapat berarti berpikir secara mendalam atau merespons terhadap kejadian, aktivitas, atau pengetahuan yang baru diterima. Melalui cara berpikir secara mendalam, dapat membantu siswa untuk memahami materi lebih jauh. Sabilu (2008)dalam Setiawan (2015) menambahkan bahwa melalui jurnal belajar, para siswa dapat menuliskan secara rutin dan disiplin tentang hal yang sudah dipelajarinya, dan memperbaiki sesuatu yang masih dianggap lemah. Adanya hubungan antara jurnal belajar dan keterampilan metakognitif ini tidak dapat lepas dari strategi Jigsaw dipadu PBL. Keterampilan metakognitif menurut Corebima (2009) dapat dilihat dari kemampuan siswa dalam memaparkan jawaban atas tes penguasaan konsep biologi yang meliputi penggunaan jawaban dalam kalimat sendiri, urutan paparan jawaban runtut, sistematis dan logis, gramatika atau bahasa, alasan (analisis/evaluasi/kreasi), serta jawaban yang diberikan benar, kurang benar, tidak benar, atau tidak dijawab sama sekali. Jurnal belajar dapat dilihat berdasarkan adanya aspek konsep dasar, refleksi diri dan pertanyaan yang dituliskan mahasiswa.Menurut Danial dalam Setiawan (2015) bahwa Peningkatan keterampilan metakognitif berdasarkan sintaks Jigsaw yang dipadu dengan PBL dengan menggunakan rubrik keterampilan metakognitif ditunjukkan dengan adanya peningkatan skor dari $62 \%$ menjadi $78 \%$. Hal ini menunjukkan bahwa terjadi peningkatan sebesar $16 \%$. Hasil ini menunjukkan bahwa pembelajaran dengan menerapkan Jigsaw dipadu PBL dapat membantu mahasiswa untuk meningkatkan dan melatih keterampilan metakognitif. Beberapa penelitian lain sepakat bahwa PBL berpengaruh dan meningkatkan keterampilan metakognitif. Suratno (2009) dan Yuwono (2014) dalam Setiawan (2015) mengungkapkan bahwa strategi pembelajaran Jigsaw mampu untuk meningkatkan keterampilan metakognitif siswa. Pembelajaran kooperatif Jigsaw berpotensi memberdayakan keterampilan metakognitif mahasiswa karena sintaks pembelajaran kooperatif Jigsaw membantu mereka belajar saling membantu, berdiskusi, dan berargumentasi untuk memahami, mengerti, dan mengetahui suatu topik secara bersama, serta menuntut tanggung jawab individu untuk menguasai materi ajar. Penelitian lain tentang model pembelajaran yang dapat memberdayakan kemampuan 
metakognitif antara lain yang dilakukan oleh Tosun C, Senocak E, ( 2013 ) hasil penelitiannya menyimpilkan bahwa Problem Based Learning (PBL) lebih efektif dalam mengembangkan tingkat kesadaran metakognitif pada siswa larar belakang pengetahuan rendah dibandingkan siswa dengan latar belakang pengetahuan tinggi. PBL dapat meningkatkan sikap positif pada siswa dengan latar belakang sikap ilmiah rendah. Penelitian yang terkait PBL dilakukan juga oleh Kevin Downing,et,al (2011) dalam Penelitiannya membandingkan antara penggunaan PBL dan metode tradisional terhadap pengembangan Pengalaman dan metakognitif siswa. Hasil menunjukkan terdapat perbedaan signifikan pengembangan Pengalaman dan metakognitif siswa antara yang menggunakan PBL dan metode tradisioanal. PBL dapat memberdayakan pengembangan metakognisi dan peningkatan pengalaman belajar. Dalam mengkaji kemampuan metakognitif, digunakan model pembelajaran kooperatif yang lain yaitu Think Pair Share yang dilakukan Chikmiyah (2012) bertujuan untuk mengetahui hubungan antara pengetahuan metakognitif dengan hasil belajar pada materi Larutan Penyangga.Setelah diterapkan pengetahuan metakognitif melalui model pembelajaran kooperatif tipe Think Pair Share, hasil penelitian menunjukan bahwa terdapat hubungan yang sangat kuat antara pengetahuan metakognitif dan hasil belajar siswa yaitu dengan hasil koefisien korelasi sebesar 0,809 . Harga $r$ hitung $(0,809)$ lebih besar dari r-teoritik dengan $\mathrm{N}=39$ pada taraf signifikan $1 \%$ sebesar 0,408 , sehingga dapat dinyatakan bahwa korelasi antara pengetahuan metakognitif dan hasil belajar siswa signifikan. Selain itu Lesson Study juga dapat memberdayakan kemampuan metakognitif, hasil penelitian Marheny L et,al (2014) , hasil penelitiannya menunjukkan bahwa implementasi Lesson Study secara signifikan efektif dalam meningkatkan keterampilan metakognitif dan pemahaman konsep pada kelas yang menggunakan e-fortofolio dibandingkan dengan kelas fortofolio.

Penelitian yang dilakukan Kipnis M (2008) didasarkan pada serangkaian investigasi komprehensif jangka panjang yang dilakukan dalam konteks pengajaran kimia SMA di laboratorium menggunakan percobaan jenis penyelidikan. Para siswa yang mempelajari kimia sesuai dengan program ini terlibat dalam proses penyelidikan yang mencakup semua keterampilan penyelidikan yaitu: mengidentifikasi masalah, merumuskan hipotesis, merancang eksperimen, mengumpulkan dan menganalisis data, dan menarik kesimpulan tentang masalah dan fenomena ilmiah. Sewaktu melakukan kegiatan ini dalam kelompokkelompok kolaboratif kecil, mereka didorong untuk mendiskusikan ide-ide mereka tentang fenomena ilmiah yang mereka amati dengan teman sekelas mereka dan mereka diberikan waktu yang diperlukan untuk mencapainya. Sebuah studi kasus kegiatan penyelidikan kelompok tiga siswa dijelaskan dan dianalisis menggunakan model metakognisi yang disajikan oleh Schraw (1998). Transkrip wawancara 20 siswa dianalisis menggunakan model Flavell et al. (2002). Ditemukan bahwa ketika melakukan kegiatan penyelidikan, para siswa berlatih kemampuan metakognitif mereka dalam berbagai tahap proses penyelidikan. Analisis wawancara menunjukkan bahwa siswa yang berpartisipasi dalam penelitian menyatakan pengetahuan metakognitif mereka mengenai kegiatan penyelidikan. Dengan demikian, diklaim bahwa laboratorium jenis penyelidikan yang direncanakan dan dilaksanakan dengan benar dapat memberikan siswa kesempatan untuk mempraktekkan keterampilan metakognitif, yang dianggap dalam beberapa tahun terakhir sebagai salah satu tujuan utama dalam upaya kami untuk memperluas lingkup keterampilan belajar yang dikembangkan. melalui belajar sains.

Beberapa strategi yang sudah diteliti dalam meningkatkan kemampuan metakognitif , antara lain hasil penelitian yang dilakukan oleh Khairil (2009) dalam Sumampouw (2011) memperlihatkan bahwa struktur perkuliahan genetika memperlihatkan pola pembelajaran yaitu mahasiswa diwajibkan membaca kemudian membuat pertanyaan dan jawaban secara mandiri berdasarkan materi bacaan. Pola pembelajaran ini telah lama dikembangkan oleh Corebima dan diberi nama strategi pembelajaran Reading, Questioning and Answering (RQA). Corebima (2009) menjelaskan bahwa pada strategi pembelajaran RQA, para pebelajar 
(mahasiswa) ditugaskan membaca materi pembelajaran tertentu. Selanjutnya, atas dasar pemahaman terhadap bacaan itu, para pebelajaran diminta membuat pertanyaan secara tertulis dan menjawabnya sendiri. Substansi yang ditanyakan adalah yang penting atau sangat penting dan terkait dengan materi bacaan, sedangkan jumlah pertanyaan disesuaikan dengan keadaan. Pertanyaan dan jawaban yang dibuat secara kelompok, dipresentasikan dan ditanggapi oleh pebelajar lainnya. Corebima (2007) menyatakan bahwa dengan demikian maka aktivitas bertanya mahasiswa meningkat baik kualitas maupun kuantitasnya. Peningkatan aktivitas bertanya mahasiswa ternyata sebanding dengan capaian hasil belajar mereka pada akhir perkuliahan semua mahasiswa dinyatakan lulus. Strategi pembelajaran $R Q A$ ini digunakan pada pembelajaran Genetika berbasis metakognitif. Hasil penelitian lain yang mendukung menyatakan bahwa terdapat hubungan yang kuat antara keterampilan metakognitif terhadap hasil belajar kognitif siswa kelas $x$ pada pembelajaran Biologi dengan Penerapan Strategi Pemberdayaan Berpikir Melalui Pertanyaan (PBMP) di SMAN 9 Malang. Sumbangan keterampilan metakognitif terhadap hasil belajar kognitif adalah 52,9 \% dengan penerapan strategi Pemberdayaan Berpikir Melalui Pertanyaan (Ardila, Corebima, Zubaedah, 2012). Strategi membaca dan menulis pun dapat membantu dalam mengembangkan kemampuan metakognitif, sebagaimana penelitian yang sudah dilakukan menyimpulkan bahwa Strategi membaca yaitu mengukur efektivitas keterampilan membaca dan kesadaran metakognitif secara online yang diberikan secara langsung pada siswa tahun pertama pada mata kuliah Pengantar Biologi, hasilnya menunjukkan bahwa keterampilan metakognitif dan strategi membaca akan meningkatkan keberhasilan siswa, kesadaran metakognitif dan pemahaman bacaan (Kendra \& Volker 2014).

Dalam hubungannya dengan strtategi membaca peneliti, mengamati peranan gender dalam strategi membaca yang hasilnya menunjukkan bahwa hubungan antara gender dengan strategi membaca yakni mereka lebih suka ketika membaca buku referensi biologi. Hasil tes chi square menunjukkan adanya hubungan antara gender dengan strategi membaca. Lakilaki dan perempuan lebih menyukai strategi membaca pemecahan masalah dimana hasilnya sebanyak 212 mahasiswa, yang terdiri dari 139 mahasiswa perempuan dan 73 laki-laki. Strategi membaca pen.dukung sebanyk 69 mahasiswa ( 59 perempuan, laki-laki 13). Strategi yang paling sedikit digunakan yakni strategi membaca umum 31 orang ( 20 perempuan , 11 laki-laki).Nilai rata-rata untuk strategi membaca metakognitif dan strategi membaca pendukung menunjukkan perbedaan signifikan dengan nilai pengaruh sedang. Siswa perempuan lebih banyak menggunakan strategi membaca metakognitif daripada siswa lakilaki. Penggunaan strategi ini dengan seimbang akan membantu siswa dalam meningktkan prestasi mereka (Arsaythamby Veloo, Mariam A Rani \& Hariharan, K, 2015).

Hasil penelitian Boulware $G$ et,al (2007) menunjukkan bahwa instruksi pemahaman membaca metakognitif secara signifikan meningkatkan pencapaian akademik siswa kelas tiga dalam domain pemahaman bacaan dan kosakata atas instruksi lain yang ditawarkan kepada siswa di sekolah perbandingan. Intensitas penelitian dan instruksi sistematis strategi metakognitif menyebabkan efek positif untuk memahami teks tertulis, yang merupakan alasan untuk membaca. Penelitian lain menunjukkan ada korelasi positif antara frekuensi menggunakan strategi membaca metakognitif dan prestasi pemecahan masalah non-rutin pada siswa kelas lima dan strategi membaca metakognitif adalah prediktor pencapaian pemecahan masalah non rutin ( Sevil Buyukalan F, Mustafa Erol, Ahmed Erol, 2018). Selain strategi membaca, sudah dilakukan juga peranan strategi menulis, hasilnya menunjukkan bahwa Penugasan Menulis dengan komponen metagognitif dapat meningkatkan pembelajaran pada keseluruhan mata kuliah pengantar biologi ( Michelle, 2014).

Beberapa orang peneliti, dalam penelitiannya mengamati strategi penilaian terhadap kemampuan metakognitif. . Hasil penelitian Amy Siegesmund (2017), tentang strategi penilaian, hasilnya menunjukkan bahwa penilaian diri berpengaruh terhadap kemampuan 
metakognisi dan kemandirian siswa. Faktor-faktor yang mempengaruhinya pengajar langsung bertatap muka dengan dengan siswa dan memberi kesempatan siswa untuk mengembangkan dan menilai sendiri untuk membangun keterampilan metakognitifnya. Pendidik tidak hanya mengajarkan disiplin namun juga membantu siswa menjadi peserta didik yang mandiri yang bisa memasuki dunia profesional dan menyelesaikan berbagai masalah kompleks Dalam hal ini siswa ikut terlibat dalam mengeksplorasi kelebihan dan kekurangan lingkungan belajar mereka. Memasukkan penilaian diri ke dalam kelas akan membantu siswa bergerak menuju diri yang teratur, belajar seumur hidup dengan mandiri yang mampu menghadapi berbagai tantangan. Ada penelitian lain tentang pengaturan metakognitif melalui penggunaan rubric penilaian untk meningkatkan kemampuan berpikir , yaitu yang sudah dilakukan oleh Yasushi G, Niigata (2016) : tentang penggunaan rubric berpikir kritis, hasilnya menunjukkan bahwa Pengaturan metakognitif melalui rubrik berpikir kritis dan proses pemecahan masalah dapat meningkatkan kemampuan berpikir kritis. Ada strategi yang dilakukan dengan merancang kegiatan kurikuler yang memberdayakan kemampuan metakognitif dalam pembelajaran, baik pada perencanaan ( Planning), pemantauan (monitoring) dan Evaluasi (Evaluating), penelitian ini dilakukan oleh Nathan et.al, (2018) untuk mengetahui dampak kegiatan kurikuler pada mata kuliah pengantar biologi, hasil penelitian menunjukkan bahwa tugas yang dirancang untuk meningkatkan metakognisi dapat berdampak pada siswa selama satu semester dan dapat memberikan manfaat terbesar bagi siswa yang berkinerja rendah. Ellis Arthur, David W Denton dan John B (2013) melalukan penelitian yang merangkum praktik pembelajaran khusus untuk meningkatkan kapasitas siswa untuk berpikir metakognitif.

Berdasarkan pembahasan tersebut, model pembelajaran kooperatif memiliki kecenderungan dalam meningkatkan kemampuan metakognitif yang memberi pengaruh terhadap meningkatnya prestasi belajar siswa. Hal ini dapat terjadi karena pembelajaran kooperatif memberdayakan siswa melalui kegiatan belajar yang saling membantu, berdiskusi, dan berargumentasi untuk memahami, mengerti, dan mengetahui suatu topik secara bersama, serta menuntut tanggung jawab individu untuk menguasai materi ajar. Kondisi ini akan melatih siswa untuk berpikir tingkat tinggi disbanding dengan pembelajar yang difasilitasi sendiri-sendiri, misalnya berlatih melakukan penalaran, berpikir kritis, memecahkan masalah yang dalam pelaksanaan pembelajarannya dapat merealisasikan kegiatan planning, monitoring dan evaluating yang merupakan komponen regulation pada metakognitif.

\section{KESIMPULAN}

Kemampuan metakognitif yang meliputi pengetahuan metakognitif dan pengaturan metakognitif merupakan kemampuan yang diharapkan dimiliki oleh siswa dalam belajar. Kemampuan metakognitif ini berkaitan erat dengan proses-proses kognitif. Kemampuan berpikir tingkat tinggi seperti berpikir kritis, berpikir kreatif, bernalar, memecahkan masalah dapat berkembang dengan baik, salah satu faktor pendukungnya yaitu jika siswa tersebut memiliki kemampuan metakognitif yang baik. Oleh karena itu, menjadi suatu alasan bagi para peneliti untuk melakukan penelitian dalam upaya meningkatkan kemampuan metakognitif siswa. Sudah banyak hasil penelitian yang mengamati berbagai strategi atau model-model pembelajaran kooperatif yang dapat meningkatkan kemampuan metakognitif, seperti model Problem Based Learning, Inkuiry, Think Pair Share, Lesson Study dan yang lainnya. Begitu juga berbagai strategi sudah dilakukan, seperti strategi bertanya, membaca, menulis, penilaian, penugasan dan tentu masih ada strategi yang lainnya. Berdasarkan kenyataan ini, selayaknya jika kita yang terlibat dalam dunia pendidikan berperan aktif dalam mengembangkan kemampuan metakognitif melalui berbagai penelitian yang relevan. 


\section{DAFTAR PUSTAKA}

Anderson, L.W., dan Krathwohl, D.R. 2001. A Taxonomy for Learning,Teaching, and Assesing: A Revision of Bloom's Taxonomy of Educatioanl Objectives. New York: Addison Wesley Longman, Inc

Boulware-Gooden, R., Carreker, S., Thornhill, A., \& Joshi, R. (2007). Instruction of Metacognitive Strategies Enhances Reading Comprehension and Vocabulary Achievement of Third-Grade Students. The Reading Teacher, 61(1), 70-77.

Chikmiyah, 2012, Relationship Between Metacognitive Knowledge And Student Learning Outcomes Through Cooperative Learning Model Type Think Pair Share On Buffer Solution Matter, Journal of Chemical Education, Vol I No.1

Corebima, A, D. 2007. Pemberdayaan Kontruktivisme dan strategi Metakognitif pada Perkuliahan Genetika Di Jurusan Biologi UM. (Laporan Teaching Grant. Universitas Negeri Malang)

Diella, D. (2014). Hubungan Kemampuan Metakognisi dengan Keterampilan Berpikir Kritis dan Sikap IImiah Siswa Kelas XI Pada Materi Sistem Ekskresi Manusia. Program Studi Pendidikan Biologi Sekolah Pascasarjana Universitas Pendidikan Indonesia.Tesis. Tidak dipublikasikan

Ellis Arthur K. , David W. Denton, John B, 2013, sAn analysis of research on metacognitive teaching strategies, J Procedia - Social and Behavioral Science Vol.116 ( 4015 - 4024)

Flavel, J.H.1979 Metacognition And Cognitive Monitoring, A New Area Of Cognitive". Development Inquiry. J American Phys. 34 p 906-911

Gurcay D, Ozturk H, 2018 , High School Students' Critical Thinking Related to TheirMetacognitive Self-Regulation and Physics Self-Efficacy Beliefs, Journal of Education and Training Studies, vol.6,No.4

Griffin, P., McGaw, B. and Care, E. (eds). 2012. Assessment and Teaching of 21st Century Skills. Dordrecht, NL, Springer.

Hill Kendra, Volker S. Brözel, Greg A. Heiberger, 2014 , Examining the Delivery Modes Of Metacognitive Awareness and Active Reading Lessons in a Collage Non majors Introductory Biology Course, J of Micro \& Bio Edu, p 5-12

Haryani, S. (2011). Pengembangan Model Praktikum Kimia Analitik Instrumen Berbasis Masalah Untuk Meningkatkan Metakognisi Mahasiswa Calon Guru. Program Studi Pendidikan IPA Sekolah Pascasarjana Universitas Pendidikan Indonesia. Disertasi. Tidak dipublikasikan

Kevin Downing et,al, 2011, Impact of problem-based learning on student experience and metacognitive development, Multicultural Education \& Technology Journal 5(1):55-69

Kipnis M, 2008, The Inquiry Laboratory as a Source for Development of Metacognitive Skills, International Journal of Science and Mathematics Education 6(3):601-627

Lai, E.R. (2011). Metacognition: a Literature Review. (Online) Tersedia:www.pearsonassessment.com/.../metacognition_literature_review_Final.pd f.(20 Maret 2017).

Livingston, J.A. (1997). Metacognition: An Overview Jennifer A.Livingston. (Online) Tersedia: http://gse.buffalo.edu/fas/shuell/cep564/metacog.htm. (15 Maret 2017)

Marheny L et,al.(2014), Lesson Study in Improving the Role of e-Fortofolio on The Metacognitive Skill and Comprehension : A Study on Cell Biology Subject in IKIP PGRI Madiun Indonesia, American Journal of Educational Research, vol 2, No $10: 919$ - 924

Murtadho, Fathiaty. 2013. Berpikir Kritis dan Strategi Metakognisi: Alternatif Sarana Pengoptimalan Latihan Menulis Argumentasi. Makalah Disampaikan pada 2 nd International Seminar on Quality and Affordable Education (ISQAE 2013). [online]. Tersedia : educ.utm.my/wpcontent/uploads/2013/11/71.pdf. [12 Januari 2016]

Marzano, Kendall,2008, Designing Educational Objectives Thousand Oaks California, Corwin Press Magno, C. (2010). The Role of Metacognitive Skills in Develoving Critical Thinking. (online) Tersedia: http//www.academia.edu. (20 Maret 2017) 
Mynlieff Michelle et,.al, 2014 Writing Assignments with a Metacognitive Component EnhanceLearning in a Large Introductory Biology Course. .J Life Sci. Edu 13 p 311-321

Nathan et,al, 2018, Curricular Activities that Promote Metacognitive Skills Impact Lower- Performing Students in an Introductory Biology Course, Journal of Microbiology \& Biology Education , vol 19, No 1 Ormrod, Jeanne Ellis. 2009. Psikologi Pendidikan. Jakarta : Erlangga.

Siegesmund A., 2017 , Using self Assessment to develop Metacognition and Self Regulated Leaners, FEMS Journal 364

Sastrawati, Eka. dkk. 2011. Problem Based Learning, Strategi Metakognisi, dan Ketermpilan Berpikir Tingkat Tinggi Siswa. Tekno-Pedagogi, 1 (2). [ online ].

Sevil Büyükalan Filiz', Mustafa Erol, Ahmet Erol, 2018. Investigating the Correlation between the Frequency of Using Metacognitive Reading Strategies and Non-routine Problem Solving Successes in Fith Grade Students, Universal Journal of Educational Research 6(8): $1795-180$

Setiawan, Susilo,2015, Peningkatan Keterampilan Metakognitif Mahasiswa Program Studi Biologi melalui Penerapan Jurnal Belajar dengan Strategi Jigsaw dipandu PBL Berbasis Lesson Study pada Mata Kuliah Biologi Umum, Prosiding Seminar Nasional Pendidikan Biologi, Pendidikan Biologi UM, Malang.

Sumampouw, H, M. 2010. Pembelajaran Genetika berbasis Metakognitif. Makalah Disajikan Pada Seminar Nasional di FMIPA UM. Tema Peran MIPA dalam Mengem-bangkan Teknologi dan Pendidikan Karakter.

Sumampouw, 2011, Keterampilan Metakognitif dan Berpikir Tingkat Tinggi dalam Pembelajaran Genetika (Artikulasi Konsep dan Verifikasi Empiris), Bioedukasi,Volume 4, Nomor 2 ,FPMIPA, Universitas Negeri Manado

Simamora, Merry C.dkk. 2014. Analisis Kemampuan Metakognisi Siswa Dalam Pembelajaran Biologi Melalui Asessment Pemecahan Masalah di SMA Negeri 5 Kota Jambi. [Skripsi]. FKIP Universitas Jambi. Tidak diterbitkan.

Taccasu Project, 2008, Metacognition, tersedia pada http://www.careers.hku.hk./taccasu/ref/metagogn.htm, diakses pada 19 Mei 2018

Tosun C, Senocak E, 2013, The Effect of Problem Based Learning on Metacognitive Awareness and Attitude Toward Chemistry of Prospective Teachers With Different Academic Background, Australian Journal of Teacher Education, vol.38, no.3

Vello A. et.al 2015 Assessing Matriculation Colledge Students'Metacognitive awareness Reading Strategies (MARS) in Biology, Rev. of European Studies

Veloo A, Mariam A Rani \& Hariharan, 2015 The Role of Gender in the Use of Metacognitive Awareness Reading Strategies among Biology Students. J Asean Social Science. $11 \mathrm{p}$ 67-73

Yasushi Gotoh, 2016, Development of Critical Thinking With Metacognitive Regulation , Inter. Conf. on Cognition and Exploratory J (CELDA,2016) p 353 -356 